\title{
Monostyrene Intake in Albino Rats: Accumulation in Organs and Effects on Growth Performance and Oxidative Stress
}

\author{
Mohamed G. El-Ziney ${ }^{1, ~}$, Hana BaAbdoulah ${ }^{2}$, Manal S. Tawfik ${ }^{3}$ \\ ${ }^{1}$ Department of Dairy Science and Technology, Faculty of Agriculture - Al Shatby, Alexandria University, Alexandria, Egypt \\ ${ }^{2}$ Department of Nutrition, King Saud University, Riyadh, Saudi Arabia \\ ${ }^{3}$ Department of Food Science and Technology, Faculty of Agriculture - Al Shatby, Alexandria University, Alexandria, Egypt
}

\section{Email address:}

elziney@yahoo.com (M. G. El-Ziney)

\section{To cite this article:}

Mohamed G. El-Ziney, Hana BaAbdoulah, Manal S. Tawfik. Monostyrene Intake in Albino Rats: Accumulation in Organs and Effects on Growth Performance and Oxidative Stress. International Journal of Nutrition and Food Sciences. Vol. 5, No. 1, 2016, pp. $72-79$.

doi: $10.11648 /$ j.ijnfs.20160501.21

\begin{abstract}
Monostyrene (MS) residuals are daily migrating from different polystyrene shaping containers to our foods. In the present study, the distribution, accumulation and clearness rate of MS in different organs were done by one oral gavage of sublethal dose of $500 \mathrm{mg} / \mathrm{kg}$ bwt in male albino rates. Following MS in kidney, liver and brain indicated that the highest concentration peak was reached after $3 \mathrm{hr}$. Meanwhile, the maximum and minimum levels were detected in kidney (190.6 $\mu \mathrm{g} / 100 \mathrm{~g})$ and brain $(12.8 \mu \mathrm{g} / 100 \mathrm{~g})$, respectively. After $3 \mathrm{hr}$ of styrene administration, the same decline rate was observed in the three organs. The clearness and metabolites rates of MS after $7 \mathrm{hr}$ of administration were $93 \%, 76.9 \%$ and $71.1 \%$ in kidney, liver and brain, respectively. Further, this study investigated the effects of different MS at doses $(0.1,0.3 \mathrm{and} 1.0 \mathrm{mg} / \mathrm{kg}) \mathrm{on}$ growth performance parameters included weight gain (WG), relative liver weight, food efficiency ratio (FER), protein efficiency ratio (PER) and on oxidative stress biomarker; malondialdehyde (MDA) in the plasma of male and female albino rats after 12 weeks of feeding. All tested MS concentrations showed significant effects $(P>0.05)$ on WG, FER and PER of either male or female rats compared to the control group. All these indices were more pronounced in both male and female that administrated MS at dose of $1.0 \mathrm{mg} \mathrm{MS} / \mathrm{kg}$ bwt. Only in female, relative liver weight was affected significantly at doses of 0.3 and $1.0 \mathrm{mg} / \mathrm{kg}$ bwt of MS. Significant differences $(P>0.05)$ were found among the experimental groups in malondialdehyde concentration in plasma of male and female rats; but not in nonlinear behavior. MDA concentration increased significantly $(P>0.05)$ in female plasma compared to male at all tested doses. Styrene concentration in male liver after three months at oral administration of $1 \mathrm{mg} / \mathrm{kg}$ was $1.72 \mu \mathrm{g} / 100 \mathrm{~g}$. It is concluded that MS at tested levels had affected growth performance parameters and led to increase oxidative stress which could have significant health risks. Kidney is the main organ responsible for MS elimination. More precaution should be addressed to food packaging industry to control and monitor MS release from PS food contact materials.
\end{abstract}

Keywords: Monostyrene, Dairy Polystyrene Packages, Oxidative Stress, Malonaldialdehyde, Weight Gain, Food Efficiency, Styrene Distribution in Organs

\section{Introduction}

Polystyrene (PS) is widely used in the manufacture of food contact materials (FCMs), and in $2012,50 \%$ of the domestic consumption of PS was related to food packaging and food service articles [1]. Styrene is used mainly for the production of polystyrene (PS) and styrene copolymers. It is the second most widely used monomer for production of food-contact packaging polymers [2]. Recent estimate put domestic consumption at 2600 million lbs for 2012 [1]. During the production process, the styrene monomer can become occluded in PS products and has the potential to migrate out of the FCMs and into the food. Styrene has known toxic effects on the central nervous system and neurological effects have been observed in workers continually exposed to styrene through inhalation [3]. Although no cases have been reported on the ingestion of styrene by humans, the systemic toxicity is expected to be similar to that of inhalation [3]. The USFDA regulates the amount of styrene monomer allowed in food grade PS at $1 \%$ by weight $(10,000 \mathrm{mg} / \mathrm{kg})$ for contact with non-fatty foods and at $0.5 \%$ by weight $(5000 \mathrm{mg} / \mathrm{kg})$ for contact with fatty foods [4].

The main food contact applications of polystyrene are in 
dairy products including yogurt, cream, cottage cheese, ice cream and fruit juice, meat trays, biscuit trays, egg cartons, and drink cups [5].

Styrene is classified as carcinogenic. Exposure to styrene occurs through inhalation and intake or eye and skin contact. The central nervous system (CNS) and the respiratory system are the most affected sites with symptoms include depression, weak concentration, weak muscles, fatigue, skin inflammation, sickness and dizziness. Exposure to styrene may also irritate nose, throat and eyes including the acute effects on eyes. It appears that styrene causes headache, sickness, acute drowsiness, consciousness and also nervous disorder. Styrene toxicity may lead to suspension of respiration and cardiovascular system [6-10]. In 2011, styrene was listed as "reasonably anticipated to be a human carcinogen" by the National Toxicology Panel (NTP) [11].

Human exposure to styrene may occur in the industrial areas or as a result of monostyrene migration from the polystyrene food packages or from styrene low concentrations originally existed in diets [12].

American Environmental Protection Agency (EPA) has conducted study titled National Human Adipose Tissue Survey for 1986 identified styrene residues in 100\% of all samples of human fat tissue taken in 1982 in the US. As styrene is used in plastic manufacture, it is pollutant to all kinds of packages made of polystyrene foams [13].

Styrene migration is not a new story as it was documented for the first time in 1972 and in 1976 [14-15]. Another study conducted in 1988 by the foundation for Establishment of Advancements in Science and Education proved that styrene is also found in human fatty tissues, at the levels of 8-350 $\mathrm{ng} / \mathrm{gm}$ adipose tissues, as this rate represents one third of the quantity that causes styrene negative effects on the nervous system [16].

Monostyrene migration to cream $(19.5 \%$ fat $)$ was investigated, and its concentration found was $20 \mathrm{ppb}$ after one day, and $107 \mathrm{ppb}$ after 7 days and $170 \mathrm{ppb}$ after 21 days where as in cream of ( $53 \%$ fat) reached $20 \mathrm{ppb}$ after one day and $150 \mathrm{ppb}$ after 7 days and 270 ppb after 21 days [17]. Withey and Collins [18] found that styrene migrated to full fat cream with concentration of $59 \mathrm{ppb}$ after 24 days, and the lower levels of migration was found in cheese, sour cream, yogurt, homogenized milk and honey. Tawfik and Huyghebaert [19] explained the relation between the range of migration and food ingredients i.e. the fat content.

The Joint FAO/WHO Committee on Food Additives [20] set the maximum tolerable daily intake of styrene by 40 $\mu \mathrm{g} / \mathrm{kg}$ body weight. Biedermnn et al. [21] estimated the average per capita intake of styrene, per year in Germany by approximately $0.8-4.5 \mathrm{mg}$. This range was taken from the milk, dairy products, fats, and oils in polystyrene packages. According to this study the intake of $338 \mathrm{gm}$ of dairy products and milk, and $72 \mathrm{gm}$ of fats and oils day/person may lead to daily styrene intake of $2-12 \mu \mathrm{g}$, i.e. equivalent to $0.7-$ $4.4 \mathrm{mg} /$ person/per year. This quantity is resulting from migration of styrene (5 to $30 \mathrm{ppb}$ ) from the polystyrene packages to the above mentioned diets. Human exposure to styrene has been assessed on the basis of a review of data in the published literature [2]. The authors estimated that styrene exposure for the general population is in the range of
18.2-55.2 $\mu \mathrm{g} /$ person/day $(0.3-0.8 \mu \mathrm{g} / \mathrm{kg}$ bwt) or $6.7-20.2$ $\mathrm{mg} /$ person/year (95.7-288 $\mu \mathrm{g} / \mathrm{kg}$ bwt), mainly resulting from inhalation and from food intake. More recently, Tawfik and BaAbdoulah [22] showed that the styrene intake are estimated that total dietary styrene intake was amounted to be $11.31 \mu \mathrm{g} / \mathrm{day} /$ person in Gulf area.

Styrene causes toxicity of liver and lungs in rats but its method of action is not clear, and it may be related with oxidizing strain including considerable reduction in the oxidized glutathione. Styrene is found toxic to the rat liver and lung and its basic metabolism is styrene oxide, and its effective metabolism is vinylphenol, which may lead to similar toxic effects [23]. Intake of 450 and $900 \mathrm{mg} / \mathrm{kg}$ of the body weight hindered glutathione-s- transferases activity as well as the glutathione contents in a most remarkable way [24].

The work in this paper designed to estimate the distribution and the clearness rate of styrene taken by gavage at sub-lethal dose of $500 \mathrm{mg} / \mathrm{kg}$ of body weight after 3, 5 and $7 \mathrm{hrs}$ in the liver, kidney and brain of male albino rats. Further, we studied the effects of styrene at doses of $0.1,0.3$ and $1.0 \mathrm{mg} / \mathrm{kg}$ bwt which in corresponding to the accepted daily intake (90 $\mathrm{mg} /$ person/day; http://plasticfoodservicefacts

.com/main/Safety/Safety-of-PS-Foodservice-Products) in male and female albino rats fed for 12 weeks on the growth performance parameters (weight gain, relative weight of the liver, food efficiency ratio (FER), protein efficiency ratio (PER)), plasma malondialdehyde (MDA) level as an oxidative stress biomarker and accumulated styrene level in liver.

\section{Materials and Methods}

\subsection{Distribution and Clearness of MS in Liver, Kidney and Brain of Male Albino Rats}

\subsubsection{Design of Experiment}

This experiment is designed to identify distribution, accumulation and clearness rate of styrene in different male rat organs (liver, kidneys and brain). Male rats $(200 \pm 5 \mathrm{gm})$ were gavage by sub-toxic doses of styrene at concentration of $500 \mathrm{mg} / \mathrm{kg}$ of the body weight. After $3 \mathrm{hrs} 3$ rats were slay, then 3 other rats were also slay after $5 \mathrm{hrs}$ and the last 3 rats after $7 \mathrm{hrs}$. The liver, kidney and brain of each rat were excised and their weights were recorded after being washed with physiological solution and kept in packages then froze at $-80^{\circ} \mathrm{C}$ until conducting the experiment of styrene estimation in those organs [25].

\subsubsection{Styrene Extract from Organs}

The frozen organ was homogenized by automatic electric homogenizer, then $30 \mathrm{ml}$ of distilled water and $15 \mathrm{ml}$ of acetontrile, and $1 \mathrm{ml}$ of calcium chloride (20\%) were added and mixed and then transferring the product to a ball-shaped flask attached to the distillation device, and after that the product was distilled after being exposed to $85^{\circ} \mathrm{C}$ at maximum, so as to delay the distillation process, and 15-20 $\mathrm{ml}$ of the distillation product was collected [26]. The distilled solution was concentrated by the rotary evaporator (Buchi Heating Bath- B-490, Germany) to $2 \mathrm{ml}$ and alpha methyl styrene was added. The sample was injected in liquid Chromatography (HPLC). 


\subsection{Effects of MS at Different Doses on the Growth Performance and Oxidative Stress Parameters in Male and Female Albino Rats}

\subsubsection{Experimental Animals}

In this experiment 40 male and female rats, type Wistar Albino, $200 \pm 5 \mathrm{gm}$ for male and $150 \pm 5$ gm for female, 6-8 weeks old were used. All rats were obtained from the animal house at King Khalid University Hospital (Faculty of Medicine, King Saud University) and experiment was made to rats for 12 weeks. The proper conditions were provided for the rats by reference feeding for one week, and then preparing the animal house with suitable environmental conditions as the rats were put separately in anti-corrosion cages, with $24{ }^{\circ} \mathrm{C}$, and $50-65 \%$ relative humidity, with a darkness/light cycle for $12 \mathrm{hrs}$. Diets and water were available during the period of experiment for the rats with daily change of water. Rats were weighed twice a week and the daily dietary intake was calculated during the experiment period.

\subsubsection{Diets Used in Experiment}

The diet used in this experiment was prepared according to the recommendations of American Institute of Nutrition [27]. Table (1) explains the quantity of raw material in the diet used. The diet is kept in $\left(4^{\circ} \mathrm{C}\right)$ through the period of experiment and the same diets with styrene doses were given to different groups of rats (Table 2).

Table 1. Quantity (gm/100 gm) of raw materials in the control diet used in experiment*.

\begin{tabular}{ll}
\hline Dietary Items & Quantity $(\mathbf{g m})$ \\
\hline Casein & 20 \\
Sorghum Starch & 51 \\
Sucrose & 15 \\
Soy Beans Oil & 4 \\
Cysteine & 0.3 \\
Mixed Metals AIN & 3.5 \\
Mixed Vitamins AIN & 1 \\
Colin Bitrate & 0.2 \\
Cellulose & 5 \\
Water & Available \\
\hline
\end{tabular}

* Source (Reeves, 1997).

Table 2. Rats experimental groups (male-female) as per styrene doses.

\begin{tabular}{ll}
\hline Groups & Diet and styrene doses \\
\hline 1 & Control diet* \\
2 & Control diet $\pm 0.1 \mathrm{mg}$ styrene $/ \mathrm{kg}$ of the body weight \\
3 & Control diet $\pm 0.3 \mathrm{mg}$ styrene $/ \mathrm{kg}$ of the body weight \\
4 & Control diet $\pm 1.0 \mathrm{mg}$ styrene $/ \mathrm{kg}$ of the body weight \\
\hline$*$ Control diet in Table (1)
\end{tabular}

\subsubsection{Rats Fed with Styrene}

Male and female rats were divided into 4 groups for each type (5 rats in each group), and each rat was put in stainless steel cage. Rats were given different gavage doses of styrene $(0.1,0.3,1 \mathrm{mg} / \mathrm{kg}$ of the bwt). Table (2) shows the experimental groups of rats as per styrene dosage.

At the end of experiment, rats left fasting for $12 \mathrm{hrs}$, then they were anesthetized with diethylether, and blood was taken with puncture heart in pipes that contain anti-blood clotting material (Ethylene Diamine Tetra Acetic acid, EDTA). Plasma was directly separated from the blood samples by centrifugal device 6000 cycle for $20 \mathrm{~min}$. (Digisystem laboratory instrument, L NC Taiwan, ROC). Plasma was taken (upper part) with thin absorber and kept in pies at $-20^{\circ} \mathrm{C}$ until estimating the malondialdehyde (MDA).

\subsubsection{Relative Liver Weight}

Male rat livers were excised and washed in a physiological solution $(0.85 \%$ sodium chloride $)$, then dried by two filtering papers with smooth pressing by hands, then directly being weighted, and in accordance with relative weight, as per the formula,

Relative liver weight $=($ liver weight/body weight $) \times 100$ [26]

\subsubsection{Acquired Weight and Food Efficiency Ratio (FER)}

The rats acquired weight is computed based on increment in the rat weight during the period of experiment according the formula,

Acquired weight $=$ rat weight at slaying - rat weight at the beginning of experiment,

The quantity of diet intake (dietary intake) is computed through the experiment period from the formula,

Dietary intake $=$ total daily diets for the rat - total daily missing food,

and the food efficiency ratio (FER) was computed according to the formula,

$$
F E R=(\text { acquired weight/dietary intake }) \times 100 .
$$

\subsubsection{Protein Efficiency Ratio (PER)}

As the protein ratio (casein) in diet is $20 \mathrm{gm} / 100 \mathrm{gm}$ fodder, thus, the consumed protein $=$ (quantity of dietary intake/100) $\times 20$ and then calculation of (PER) as formula,

$$
P E R=(\text { acquired weight/quantity of protein }) \times 100 .
$$

\subsection{Oxidative Stress Biomarker: Estimation of Malondialdehyde in Blood Plasma}

Malondialdehyde (MDA) levels in plasma were estimated by applying the colorimetric method using the thiobarbituric acid (TBA) [28].

\subsection{Determination of Monostyrene by HPLC}

Styrene concentration was estimated by high performance liquid Chromatography as it was described by Tawfik and Huyghebaert [19]. Briefly, HPLC (Bio-TEK) with UV/VIS absorbance detector and a data module integrator/recorder was used. The column $(250 \times 4.6 \mathrm{~mm})$ was packed with Lichrosorb RP-18 $(10 \mu \mathrm{m})$ and the mobile phase was distilled water-acetonitrile $(25 \%-75 \%)$ at flow rate of $1.0 \mathrm{ml} / \mathrm{min}$. The system is connected with automatic sample injector (BioTEK), the peak areas under the curve were calculated using a computer (Chromatopac Software, Karosystem 2000, version 1.83 integration). Sample injection volume was $50 \mu 1$. The detector was set at $245 \mathrm{~nm}$.

\subsection{Statistics Analysis}

Statistical analysis was performed using SPSS statistical 
software (version 16.0; SPSS Inc., Chicago, IL, USA). The $p$-values for the differences were calculated using the Chisquare or Fischer's exact test. All significance tests were twotailed and $\mathrm{P}<0.05$ was considered significant.

\section{Results and Discussion}

\subsection{Distribution and Clearness of MS in Kidney, Liver and Brain of the Male Rats}

Table (3) shows the effect of the sub-lethal oral dose of monostyrene $(500 \mathrm{mg} / \mathrm{kg}$ of body wt.) on its accumulation and clearness in some male rat organs. It is postulated that the highest styrene level approached after $3 \mathrm{hrs}$ in kidney, liver and brain. As is expected, the highest MS level accumulated was noticed in kidney (190.61 $\mu \mathrm{g} / 100 \mathrm{gm})$. In kidneys the styrene decreased significantly after $5 \mathrm{hrs}$ by $79.2 \%$ and continued to fall down after 7 hrs. In the liver, the styrene accumulation and clearness had a less ratio than in kidney and dropped by $76.9 \%$ after 5 hrs. After 7 hrs, styrene accumulated and not metabolized and/or excreted (Table 3).

Table 3. Accumulation and clearness rate of monostyrene after 3, 5 and $7 \mathrm{hr}$ in kidney, liver and brain of male rat gavage with one sub toxic styrene dose of $500 \mathrm{mg} / \mathrm{kg} \mathrm{bwt}$.

\begin{tabular}{llll}
\hline Organs & \multicolumn{4}{l}{ MS concertation $(\boldsymbol{\mu g} / \mathbf{1 0 0}$ gm of liver wt) } \\
\hline Kidney & $190.61 \pm 3.22^{\mathrm{aA} *}$ & $39.58 \pm 7.20^{\mathrm{aB}}$ & $13.00 \pm 4.30^{\mathrm{aC}}$ \\
Liver & $47.67 \pm 1.08^{\mathrm{bA}}$ & $11.02 \pm 0.36^{\mathrm{bB}}$ & $11.00 \pm 0.11^{\mathrm{bB}}$ \\
Brain & $12.81 \pm 3.87^{\mathrm{cA}}$ & $8.54 \pm 0.86^{\mathrm{cA}}$ & $3.70 \pm 0.09^{\mathrm{cB}}$ \\
\hline
\end{tabular}

* Average \pm Standard Error $(n=3)$. Averages carrying similar capital letters (A, B, C) in the same row indicates no significant differences. Average carrying similar small letters $(\mathrm{a}, \mathrm{b}, \mathrm{c})$ in the some column indicates no significant differences.

After 3 hrs, the brain had the lowest accumulated styrene level $(12.81 \mu \mathrm{g} / 100 \mathrm{gm})$ in compared with kidney and liver. Further, the lower clearness rate was observed in brain as styrene decreased only by $33.3 \%$ after $5 \mathrm{hrs}$ of oral administration. This is reflected as the highest styrene residual percent was found in brain $(28.8 \%)$ followed by liver $(23 \%)$ then in kidney $(6.8 \%)$ after 7 hrs of intake compered to concentration at $3 \mathrm{hrs}$. Time has an obvious role in styrene accumulation in liver and the higher accumulation appeared in kidneys and this is due to styrene conversion to mandelic acid (MA) and phenylglyoxylic acid (PGA) in urine according to styrene metabolism so as to be discharged through urine. The part which was not transformed metabolically from styrene remains accumulating in kidneys [29].

Styrene was estimated in more than one organ, as it is also stated by Leibman [25]. in which he proved that styrene exists in different organs such as liver, kidneys, brain, pancreas, lung, intestine, gastro, heart, bones, lipoid tissues and blood, and it also exists in urine, stool, and exhalation air when the rats exposed to concentrations varied between $11-12 \mathrm{mg} / \mathrm{kg}$ for 1-6 hours, and styrene level existing in liver, kidneys and brain will be high after one hour from exposure, then decreases after 6 hours due to different metabolic styrene conversion in the body as [30]. enumerated 533 compounds that led to occurrence of cancer in the body by its existence in different organs, and among these, the styrene compound.

It is worth mentioning, that $60-70 \%$ of styrene that enters the body will be absorbed and high ratio of the absorbed part transforms into mandelic acid (MA) and disposed through urine and so far the remaining quantity or residue it may accumulate in the organs or lipoid tissues [31]. Which explain the appearance of styrene in kidneys and other organs. Increase and decrease of styrene in different organs may be attributed to that when the rats exposed to high styrene dose which convert it to styrene oxide through the cytochrome path (P-450) and finally be converted to mandelic acid (MA) in urine, but styrene in other direction will be oxidized on the aromatic ring leads to the formation of 3, 4-arene oxide, which may contribute to induce breaking of DNA double strands [32]. At this point the cell loses its ability to produce cytochrome P-450 at the level of m-RNA, then increment in the liver styrene ratio may occur, and also by high styrene dose, the DNA loses the capacity of repair (DNA Repair) which results in increasing the rate of accumulation [32]. It is obvious from the results that the increased rate of accumulation in liver is associated with increment of accumulation ratio in kidneys.

Carlson [33] stated that high styrene concentration results in decaying the liver tissues, due to the vital activity of styrene and its conversion to styrene oxide in these tissues. Liver is the basic organ in styrene metabolism and other organs such as kidneys, stomach, lung and skin are able to dispense with and convert styrene to styrene oxide [34] . WHO [35] indicated that styrene absorbed through gastrointestinal tract after oral intake during 4-6 hrs of intake and the kidneys inhibit high concentrations. It was also absorbed by liver and pancreas, and $90-95 \%$ of styrene disposition through urine and $2 \%$ through stool, and styrene has not widely spread and distributed in the body and it is found in the lipoid tissues. Styrene removal is slow which led to its accumulation in the body and to toxicity of the organs in which it exists.

American Cancer Institute conducted a study in 1978 and came to conclusion that there is a direct relation between the mortality rate and the dose for the male rats, while exhaustion related to the dose and effect on the average body weight was observed in females. As for the rats type $\mathrm{B} 6 \mathrm{C} 3 \mathrm{~F}$, fed with styrene doses 150 and $300 \mathrm{mg} / \mathrm{kg}$ of the body weight, it was observed that the male rats were infected by lung glandular swelling and neurofibromatosis, and females affected only by fibromatosis after 78 weeks from the date of experiment [36]. In Ponomarkov and Tomatis study [37] the pregnant rats were given styrene dose of $1350 \mathrm{mg} / \mathrm{kg}$ bwt by gavage or oral injection (dissolved in olive oil). In the rats died before the twenty week, it was observed that there was a hole in the liver core, deficiency in growth of tissues, and acute congestion in the lung. As for the rats died after the 45th week, cavities similar to abscess in liver filled with white blood cells were noticed, and lung glandular swelling and carcinoma were also observed in males and females. The experiments terminated due to increment of dead rats. The same dose of styrene taken during the 17 th day of pregnancy has led to swellings more in mothers than in the newborn rats. The newborn rats fed with $500 \mathrm{mg}$ of styrene $/ \mathrm{kg}$ of the body weight for 120 weeks resulted in mortality rate of $10 \%$ of these rats and affected by neurenteric swellings, but that dose did not affect the average body weight of the newborn 
rats. Ottawa federal state [38] investigated the effect of oral styrene intake, and found clotting in the rats liver, which given $500 \mathrm{mg} / \mathrm{kg}$ of the body weight after slaying, and the same symptoms were observed for the rats with $320 \mathrm{mg} / \mathrm{kg}$ styrene of the body weight.

IARC [39] showed that styrene intake by gastro tube has resulted in increment of the lung cancer in male rats and glandular swellings in the liver cells of female rats and no increment occurred in cancer effects. Exposure before delivery followed by gastro tube after delivery had led to a significant increase in occurrence of the lung cancer in male rats, and no increment observed in affection by cancer in rats. Semi chronic effects of styrene and styrene oxide on fats oxidation, and glutathione enzyme concentration and reductase glutathione activity in liver and brain of rats fed with doses of 300,400 and $500 \mathrm{mg}$ styrene oxide $/ \mathrm{kg}$ of the body weight and 200 and $300 \mathrm{mg}$ styrene $/ \mathrm{kg}$ of the body weight were investigated. It appears that the fat increased in the liver of rats treated with high doses of styrene oxide (400 $\mathrm{mg} / \mathrm{kg}$ of the body weight). No change was observed in the brain, and huge reduction has occurred in the glutathione content (GSH). The results supposed that the liver fats after treatment with styrene or styrene oxide occurred as a result of frequent exhaustion of glutathione [40].

\subsection{Effects of MS at Different Doses on the Growth Performance Parameters in Rats}

Tables (4) and (5) show the effects of stable dietary intake by male and female albino rats in addition to intake of dissolved styrene in sorghum oil $(0.1,0.3$ and $1.0 \mathrm{mg} / \mathrm{kg}$ of the body wt.) for 12 weeks compared to control group which consumed a stable diet on the acquired weight (gm), relative liver weight, food efficiency ratio (FER) and protein efficiency ratio (PER). It was noted that there were significant differences in the acquired weight of males rats with different concentrations of styrene (Table 4). The fourth group (1.0 mg styrene/kg bwt) showed highest decrease in weight by $10.9 \%$ with a less acquired weight of $195 \pm 6.2 \mathrm{gm}$ while, the acquired weight in the control group was $219 \pm 3.1$ gm.

Food efficiency ratio (FER) ranged between $11.31 \pm 0.74$ and $8.56 \pm 0.48$ with significant differences between all experimental groups in compare to control group (Table 4). It was noted that there were significant differences in protein efficiency ratio (PER) as the values ranged between $56.51 \pm 2.22$ and $44.23 \pm 3.02$ in the control group and the fourth group. The relative liver weight reached $3.29 \pm 0.16 \mathrm{gm}$ in the control group and $3.35 \pm 0.10 \mathrm{gm}$ in the group fed with $1.0 \mathrm{mg}$ styrene $/ \mathrm{kg}$ bwt, despite that, no significant differences were found (Table 4). This indicates that styrene intake with tested doses has a significant effect on the acquired weight, FER and PER but not on relative liver weight.

Table (5) shows the effect of intake of different styrene doses by female rats compared to the control group on the acquired weight, which leveled to $99 \pm 6.26$ gm in control group and $66 \pm 6.6 \mathrm{gm}$ in the fourth group. This result indicated that the styrene has a higher effect on the acquired weight in female (decreased by $33.3 \%$ ) than in male rats. Further, in female rats, styrene doses of 0.3 and $1 \mathrm{mg} / \mathrm{kg}$ of body wt had led to a significant decrease in FER, PER and the average wt. of liver (Table 5).

Table 4. Effects of intake of monostyrene for 12 weeks on growth efficiency parameters in the male rats.

\begin{tabular}{lcccc}
\hline Experimental Groups* & Acquired wt. (gm) & $\begin{array}{c}\text { Relative liver weight } \\
\text { (gm/100gm bwt) }\end{array}$ & $\begin{array}{c}\text { Food efficiency ratio } \\
\text { (FER) }\end{array}$ & $\begin{array}{c}\text { Protein efficiency ratio } \\
\text { (PER) }\end{array}$ \\
\hline Group (1) & $219 \pm 3.1^{\mathrm{a} * *}$ & $3.29 \pm 0.16^{\mathrm{a}}$ & $11.31 \pm 0.74^{\mathrm{a}}$ & $56.51 \pm 2.22^{\mathrm{a}}$ \\
Group (2) & $212 \pm 4.4^{\mathrm{b}}$ & $3.27 \pm 0.07^{\mathrm{a}}$ & $9.44 \pm 0.93^{\mathrm{b}}$ & $47.19 \pm 4.65^{\mathrm{b}}$ \\
Group (3) & $206 \pm 9.4^{\mathrm{b}}$ & $3.32 \pm 0.06^{\mathrm{a}}$ & $9.23 \pm 0.36^{\mathrm{b}}$ & $46.18 \pm 1.80^{\mathrm{b}}$ \\
Group (4) & $195 \pm 6.2^{\mathrm{c}}$ & $3.35 \pm 0.10^{\mathrm{a}}$ & $8.56 \pm 0.48^{\mathrm{c}}$ & $44.23 \pm 3.02^{\mathrm{c}}$ \\
\hline
\end{tabular}

*Treatment groups: 1, 2, 3 and 4 corresponding to $0,0.1,0.3$ and $1.0 \mathrm{mg} \mathrm{MS} / \mathrm{kgbwt}$ respectively

** Average \pm standard error (SE) $(n=5)$. Average that carries similar letters in each column means that no significant differences were found.

Table 5. Effects of intake of monostyrene for 12 weeks on growth efficiency parameters in the female rats.

\begin{tabular}{|c|c|c|c|c|}
\hline Experimental Groups* & Acquired wt. (gm) & $\begin{array}{c}\text { Relative liver weight } \\
\text { (gm/100gm bwt) }\end{array}$ & $\begin{array}{c}\text { Food efficiency ratio } \\
\text { (FER) }\end{array}$ & $\begin{array}{c}\text { Protein efficiency ratio } \\
\text { (PER) }\end{array}$ \\
\hline Group (1) & $99.00 \pm 6.26^{\mathrm{a} * *}$ & $3.04 \pm 0.09^{\mathrm{a}}$ & $6.75 \pm 0.73^{\mathrm{a}}$ & $36.76 \pm 1.19^{\mathrm{a}}$ \\
\hline Group (2) & $81.60 \pm 3.44^{\mathrm{b}}$ & $3.35 \pm 0.21^{\mathrm{a}}$ & $4.67 \pm 0.29^{b}$ & $28.42 \pm 0.66^{\mathrm{b}}$ \\
\hline Group (3) & $80.80 \pm 6.40^{\mathrm{b}}$ & $3.63 \pm 0.18^{\mathrm{b}}$ & $4.34 \pm 0.50^{\mathrm{b}}$ & $26.19 \pm 1.56^{\mathrm{b}}$ \\
\hline Group (4) & $66.00 \pm 6.6^{\mathrm{c}}$ & $3.64 \pm 0.29^{\mathrm{b}}$ & $3.78 \pm 0.40^{\mathrm{c}}$ & $21.96 \pm 1.92^{\mathrm{c}}$ \\
\hline
\end{tabular}

*Treatment groups: 1, 2, 3 and 4 corresponding to 0, 0.1, 0.3 and $1.0 \mathrm{mg} \mathrm{MS} / \mathrm{kgbwt}$ respectively

** Average \pm standard error $(\mathrm{SE})(\mathrm{n}=5)$. Average that carries similar letters in each column means that no significant differences were found.

The present results showed that styrene effects depend on dose exposure level and sex type. Results of the present study agree with the research outcome of National Cancer Institute [36], which revealed that styrene doses had led to a decrease in the rats' body wt. In relation between dose level and styrene trend effect, Wolf et al. [41] showed that styrene dissolved in olive oil has no effects on female rats given low doses, but the higher dose has led to decrease of liver growth and weight.
In general most of the published result indicted the relation between the sex and styrene effects. In the study of National Technology Program [42]., it appears that when the rats exposed to styrene doses with concentrations of $62 \mathrm{ppm}$ for 5 days a week and for 13 weeks, this has led to a decrease in the weight of experimental rats compared to the control group by $9 \%$ and the effect was higher on the females compared to males, which agree with the present study. Ogleznev [43] stated that styrene dose of $0.55 \mathrm{mg} / \mathrm{kg}$ has no 
effect on the growth of male rats. However, Ponomarkov and Tomatis [37] reported there is no differences occurred in the body weights of both male and female rats with styrene intake compared to the control groups. Research of the NCI [36] stated that the male rats given various doses, their average body weight decreased in the rats consumed those doses but with a lower level compared to control group and this agree with the results of the present study. Cruzan [44] explained that high styrene concentrations had not affected the life of male rats but led to death of females after 2 weeks, which implies that styrene effect is 15 times higher in females rather than in males.

\subsection{Effects of MS on Malondialdehyde (MDA) Level in Serum Blood}

The malondialdehyde (MDA), oxidative stress biomarker in plasma is indirectly indicates the degree of oxidative stress [45]. The condensation of MDA with two molecules of 2thiobarbituric acid (TBA) has been widely used to measure the extent of oxidative deterioration of lipids in biological and food systems [46-48]. Hence, the level of oxidative stress in plasma and tissue usually correlates with MDA concentration [49].

Table (6) explains the effects of styrene intake at different doses $(0.1,0.3,1.0 \mathrm{mg} / \mathrm{kg}$ of bwt) in male and female rats on the level of malondialdehyde $(\mathrm{mmol} / \mathrm{L})$ in blood serum. The level of MDA in the male rats' serum of the control group was $0.67 \mathrm{mmol} / \mathrm{L}$ increased by $35 \%$ (1.03 $\mathrm{mmol} / \mathrm{L})$ after taking styrene at concentration of $1 \mathrm{mg} / \mathrm{kg}$ bwt. The styrene MDA effect has a linear relationship with a high correlation $\left(r^{2}=0.976\right)$ at tested styrene range (data not shown).

Table 6. Influence of monostyrene for 12 weeks on malondialdehyde (MDA) level (mmol/l) in the blood serum of male and female rats.

\begin{tabular}{lll}
\hline Sex Groups* & Male & Female \\
\hline Group (1) & $0.76 \pm 0.21^{\mathrm{aA} * *}$ & $1.02 \pm 0.17^{\mathrm{aA}}$ \\
Group (2) & $0.81 \pm 0.06^{\mathrm{aB}}$ & $1.31 \pm 0.19^{\mathrm{bA}}$ \\
Group (3) & $0.88 \pm 0.09^{\mathrm{bB}}$ & $1.36 \pm 0.16^{\mathrm{bA}}$ \\
Group (4) & $1.03 \pm 0.22^{\mathrm{bB}}$ & $1.45 \pm 0.14^{\mathrm{bA}}$ \\
\hline
\end{tabular}

*Treatment groups: 1, 2, 3 and 4 corresponding to $0,0.1,0.3$ and $1.0 \mathrm{mg}$ $\mathrm{MS} / \mathrm{kgbwt}$ respectively

**Average \pm standard error $(n=5)$. Averages carrying similar small letters (a, b) in each column means that there were no significant differences. Average carrying similar capital letters (A, B) in the same row means no significant differences.

The effect of styrene on MDA level in female rats was more pronounced. The MDA increased by $42 \%$ after administration of $1 \mathrm{mg}$ styrene/kg bwt. However, the relationship between the styrene concentration effect and MDA in female rats did not follow the same trend like in male ones with lower regression $\left(r^{2}=0.57\right.$; data not shown).

By comparing females with males, significant differences were found in favor of females including all the groups (Table 6). Therefore, it appears that low styrene concentrations in group 2 have no significant effect on the level of MDA in the blood serum of male rats, but they have significant effects among both males and females in group 3 and 4 and this reflects the influence of styrene and its conversion to styrene oxide in females more than in males.

In the study of Srivastava et al. [50], they used MDA level as fats oxidation indicator in the liver and brain of rats after taking various styrene doses. They found that fats oxidation was noted in the liver with increment of styrene dose, but in brain no significant effect was noted.

\subsection{Level of Monostyrene in the Male Rat Liver After 12 Weeks of Feeding with MS}

Table (7) shows the concentration of monostyrene in the liver of male rats after orally taking styrene $(0.1,0.3,1.0$ $\mathrm{mg} / \mathrm{kg}$ bwt) for 12 weeks. The results showed that styrene concentration only appears with administration of highest styrene level (1 mg/kg bwt) as it reached to $1.72 \mu \mathrm{g}$ styrene/100 gm meanwhile, there was no significant difference between both groups taking styrene at lower doses (0.1 and $0.3 \mathrm{mg} / \mathrm{kg}$ bwt).

Study of Sperlingova et al. [51] explained that there was no change in styrene metabolism and quantity of each mandelic acid and phenylglyoxylic acid in urine after being exposed to low styrene concentrations for 8 months. In an extended study [52] evaluated the styrene effect on two groups of experimental rats, type Wistar I, of males and females were fed with 1.0 and $5 \mathrm{mg} / \mathrm{kg}$ bwt. They were orally fed for 10 months; two swellings were observed in the peeling area of females fed with the higher dose. One swelling was observed at the fifth month of exposure and the second one at the tenth month. The evaluation of tissues indicated that all swellings created glandular fibromatosis.

Table 7. Level of monostyrene in the male rat liver after being fed with different MS concentrations for 12 weeks.

\begin{tabular}{lc}
\hline Experimental groups* & Styrene concentration $(\boldsymbol{\mu g} / \mathbf{1 0 0}$ gm of liver wt.) \\
\hline Group (2) & $<0.5^{\mathrm{a} * *}$ \\
Group (3) & $<0.5^{\mathrm{a}}$ \\
Group (4) & $1.72 \pm 0.67^{\mathrm{b}}$ \\
\hline
\end{tabular}

*Treatment groups: 2,3 and 4 corresponding to $0.1,0.3$ and $1.0 \mathrm{mg}$ $\mathrm{MS} / \mathrm{kgbwt}$ respectively

**Average \pm standard error $(\mathrm{n}=5)$. Averages carrying similar small letters $(\mathrm{a}$, b) in each column means that there were no significant differences.

\section{Conclusion}

Styrene was accumulated in and excreted out male rat organs such as liver, kidneys and brain with different levels and intervals. The highest accumulation occurred in kidney followed by liver and brain while, clearness rate was higher in kidney which passed in according to styrene metabolism in the body. There were significant effects of 12 weeks of feeding male and female albino rats with MS doses fall around accepted daily intake range on the growth performance parameters included weight gain, food efficiency ratio and protein efficiency ratio. The MS showed more pronounced effect in female than in male rats. The monostyrene could have the ability to elevate fats oxidation. The MDA level; oxidative stress biomarker, has boosted in female rats more than in male ones. These results open the discussion on the health risks of long-term exposure to migrated styrene especially, with the fact that the food 
packaging materials are not the only source of monostyrene we could exposed to. Hence, more precaution should be addressed to food packaging industry and consumer to control MS level and release from PS food contact materials.

\section{References}

[1] American Chemistry Council. The Resin Review: The Annual Statistical Report of the North American Plastic Council. [Internet]. Washington (DC): ACC. [cited 2013 Sept 5], 2013. Available from: http://www.americanchemistry.com/Jobs/EconomicStatistics/P lastics-Statistics.

[2] Tang W., Hemm I., Eisenbrand, G, Estimation of human exposure to styrene and ethylbenzene. J Toxicology 144: 3950,2000 .

[3] ASTDR's Toxicological Profiles. Toxicological Profile for Styrene. Atlanta, GA: CRC Press, 2010.

[4] Title 21 - Food and Drugs. Code of Federal Regulations 21CFR771640, 2013.

[5] Modern Plastic. Encyclopedia modern plastics. McGraw-Hill, 1991.

[6] Varner S. L., Breder C. V, Headspace sampling and gas chromatographic determination of styrene migration from food-contact polystyrene cups into beverages and food stimulants. J Assoc Off Anal Chem 64: 1122-1130, 1981.

[7] Varner S. L., Breder C. V., Fazio T, Determination of styrene migration from food-contact polymers into margarine, using Azeotropic distillation and head space gas chromatography. J Ass Offic Anal Chem Int 66: 1067-1073, 1983.

[8] Muratak A., Avakis S., Yokoyama K, Assessment of the peripheral, central and autonomic nervous system function in styrene workers. Am J Index Medicus 20: 775-784, 1991.

[9] Cohen T., Carlson G., Charnley G., Coggon D., Delzell E., Graham J. D, A comprehensive evaluation of the potential health risks associated with occupational and environmental exposure to styrene. J Toxicol Env Health B 5: 1-263, 2002

[10] Benignus V. A., Geller A. M., Boyes W. K., Philip J., Bushnell J, Human neuroben avioral effects of long-term exposure to styrene: A meta-analysis. Environ Health Perspective 113: 532-538, 2005.

[11] DHHS US. 12th Report on Carcinogens [cited 2013 Sep 5]. Available from: http://ntp.niehs.nih.gov/ntp/roc/ twelfth/roc12.pdf. 2001.

[12] Vandepaet M. L., Bogaert M. D., Meester C. D., Noel G., Poncelet F., Mercler M, Styrene induced modifications of some fat liver enzymes involved in the activation and inactivation of xenobiotics. J Biochem Pharm 28: 1653-1659, 1978.

[13] Institute for Local Self- Reliance, Washington. Are styrene food and beverage containers a health hazard. 1990.

[14] Figge K, Migration of additives from plastic films into edible oils and fat stimulants. Food Cosmet Toxicol 6: 815-828, 1972.

[15] Dowty B. J., Laseter J. L., Storet J, The tranplacental migration accumulation in blood of volatile constituents. Pediatric Res 10: 96- 101, 1976.
[16] Polystyrene Fact sheet: Support Document. Prevention and Toxics. Available from: http://www.epa.gov/opptintr/chemfct/styresd.txt. 1994.

[17] Davies J. T, Referred to in Twelfth Quarterly Technical Progress Report July 1, 1980 to September 30, 1980 on a Study of Indirect Food Additive Migration. FDA Contract 223-77- 2360, October 1980, (Cambridge, MA: A. D. Little, Inc.), pp. 46, 48-50, 1979.

[18] Withey J. R., Collins P. G, Styrene monomer in foods: a limited Canadian survey. Bulletin Environ Contamination Toxicol 19: 86-94, 1978.

[19] Tawfik M. S., Huyghebaert A, Polystyrene cups and containers: styrene migration. Food Addit Contam 15: 592$599,1998$.

[20] WHO. Toxicological evaluation of certain food additives and food contaminants. $28^{\text {th }}$ Report of the Joint FAO/WHO Expert Committee on Food Additives. WHO Food Additives Series Number19. World Health Organization, Geneva. 1984.

[21] Biedermann M., Grob K., Morhio G, On the origin of benzene, toluene, ethylbenzene and xylene in extra virgin olive oil. Z Lebensm Unters Forsch 200: 266-272, 1995.

[22] Tawfik M, S., BaAbdoullah H, Migration levels of monostyrene in most vulnerable foods handled and stored in polystyrene containers and their impact on the daily intake. Pak J Food Sci 24: 57-63, 2014.

[23] Benignus V. A., Geller A. M., Boyes W. K., Philip J., Bushnell J, Human neuroben avioral effects of long-term exposure to styrene: A meta-analysis. Environ Health Perspective 113: 532-538, 2005.

[24] Das M., Srivastava S. P., Seth P. K, Effect of styrene on glutathione content and some xenobiotic metabolizing enzymes of rat kidney. Acta Pharmacol Toxicol 52: 47-50, 1983.

[25] Leibman K. C, Metabolism and toxicity of styrene. Environ Health Perspectives 11: 115-119, 1975.

[26] Flanjak J., Sharrad J, Quantitative analysis of styrene monomer in foods. A limited East Australian Survey. J Sci Food Agric 35: 457-462, 1984.

[27] Reeves P. G, Components of the AIN-93 diets as improvements in the AIN-76A diet. J Nutr 127: 808S-814S, 1997.

[28] Esterbauer H., Cheeseman K. H, Determination of aldehydic lipid peroxidation products malondialdehyde and 4hydroxynonenal. Method Enzymes 186: 407-421, 1990.

[29] Berode M., Droz P. O., Boillat M. A., Guillemin M, Effect of alcohol on kinetics of styrene and its metabolites in volunteers and in workers. Appl Ind Hyg 1: 26-28, 1986.

[30] Gold L. S., Slone T. H., Manley N. B., Bernstein L, Target organs in chronic bioassays of 533 chemical carcinogens. Environ Health Perspect 98: 233-246, 1991.

[31] IARC. Some industrial chemicals. In: IARC Monographs, the evaluation of carcinogenic risk chemicals to human. Vol. 60, IARC, Lyon, France, 233- 320. 1994.

[32] Vodicka P., Tuimala J., Stetina R., Kumar R., Manini P., Naccarati A., Maqstri L., Vodickov L., Kuricova M., Mutti A., Imbiani M, Cytogenetic Markers, DNA single-strand breaks, urinary metabolites and DNA repair rates in styrene-exposed lamination workers. Environ Health Persectiv 112: 867-871. 2004. 
[33] Carlson G. P, Comparison of the susceptibility of wild and CYP2E1 knockout mice to the hepatotoxic and pneumotoxic effects of styrene and styrene oxide. Toxicol Lett 150: 335339, 2004.

[34] Baratsch H., Malaveille C., Montesano R, Human, rat and mouse liver-mutagenicty of vinyl chloride in S. tyhimurium strains. Int J Cancer 15: 429-437, 1975.

[35] WHO. Styrene chapter. 5: 12: 1-31, 2002.

[36] National Cancer Institute. Carcinogenesis technical report series. Bioassay of Styrene for Possible Carcinogenicity. No. 185. 1978.

[37] Ponomarkov V., Tomatis L, Effects of long-term oral administration of styrene to mice and rats. Scand J Work Environ Health 4: 127-135, 1978.

[38] IARC. Summaries and Evaluations. Styrene is possibly carcinogenic to humans (Group 2B). 60: 233. CAS, No. 10042-5. 1994.

[39] Ottawa Styrene (Canadian Environmental Protection Act. Priority Substances List assessment report, PSL-24E), Canada Communication Group. 1993.

[40] Katoh T., Higashi K., Lnouve N, Sub-chronic effects of styrene and styrene oxide on lipid peroxidation and the metabolism of glutathione in rat liver and brain. J Toxicol Sci 14: 1-9, 1989.

[41] Wolf M. A., Rowe V. K., Mccollister D. D., Hollingsworth R. L., Oyen F, Toxicological studies of certain alkylated benzenes and benzene-experiments on laboratory animals. Am Arch Int Health 14: 387-398, 1956.

[42] NTP. Pathology working group's chairperson's report. 13Week toxicity study of styrene (CO2200B) in F344 Rats and B6C3F1 Mice by inhalation. Report dated 28 April, 1992.

[43] Ogleznev G, Comparative characteristics of the toxic action of aqueous solution of methylostyrene and styrene. Tr Omskogo Med Inst 98: 164-174, 1963.

[44] Cruzan G, Chronic toxicity carcinogenicity study of styrene in CD-1 mice by inhalation exposure for 104 weeks. Appl Toxicol 21: 185-198, 2001.

[45] Lovri J., Mesi M., Macan M., Koprivanac M., Kelava M., Bradamante V, Measurement of malondialdehyde (MDA) level in rat plasma after simvastatin treatment using two different analytical methods. Periodicum Biologorum 110: 63-67, 2008.

[46] Gray J. I, Measurement of lipid oxidation: A review. J Am Oil Chem Soc 55: 539-46, 1978.

[47] Frankel E. N., Neff W. E, Formation of malonaldehyde from lipid oxidation product. Biochim Biophys Acta 754: 264-70, 1983.

[48] Melton S. L, Methodology for following lipid oxidation in muscle foods. Food Technol 37: 105-9, 1983.

[49] Anguloa J., Romera J. M., Ramirez M., Gil A, Effects of storage conditions on lipid oxidation in infant formulas based on several protein sources. J Am Oil Chem Soc 75: 1603-07, 1998.

[50] Srivastava S. P., Das M., Seth P. K, Enhancement of lipid peroxidation in rat liver on acute exposure to acrylamide and styrene a consequence of glutathione depletion. Chem Obiol Interact 45: 373-380, 1983.

[51] Sperlingova I., Dabrowska L., Stransky J., Cerar K. U., Tichy M, Priliminary study to preparc a reference a reference material of styrene metabolites-mandelic acid and phenylglyoxylic in human urine. Quality, Comparability and Reliability in Chemical Measarent 8: 113-116, 2004.

[52] Radeva M., Krustev L, Studies on the effect of styrene monomer on albino rats after long-term oral administration. Khig Zdraveopaz 25: 464-468, 1982. 